\title{
"Evaluation of Influence of Endodontic Irrigants on Fracture Resistance of Endodontically Treated Teeth Obturated with Resilon Epiphany."
}

\author{
Dr. Shaktidar PR MDS ${ }^{1}$, Dr. Kiran Kumar N MDS ${ }^{2}$, Dr. AllappanavarKeerti S \\ $\mathrm{MDS}^{3}$, Dr. Uday NM MDS ${ }^{4}$
}

\begin{abstract}
Aim:The present study involved the in vitro comparison of root reinforcing ability of resilon epiphany in endodontically treated teeth irrigated with different solutions.

Materials And Methods: 60 single rooted extracted premolars were decoronated and randomly distributed into 4 groups according to the endodontic irrigant used.Groupl (control):distilled water, Group2: 5.25\% sodium hypochlorite, Group3: 17\% EDTA, Group4: 5.25\%sodium hypochlorite and 17\% EDTA.Cleaning and Shaping was followed using the respective endodontic irrigants in each group in all 60 teeth.

All 60 teeth were obturated with resilon epiphany. After 10 days at $37^{\circ} \mathrm{C}$, the roots were mounted and subjected to fracture strength testing using a universal testing machine. Data were analyzed using a ANOVA and Tukey tests at 5\% significance.

Results: The mean force of fracture values was $269.287 \mathrm{~N}, 253.380 \mathrm{~N}, 343.733 \mathrm{~N}$ and 359.847N for groups 1,2,3 and 4 respectively. There was a significant difference $(p<0.01)$ between the groups. Group 1 and 2 showed higher fracture resistance as compared to group 3 and 4. There was no significant difference $(p>0.01)$ between groups $1 \& 2$ and between groups $3 \& 4$.

Conclusion: the results of this study suggest teeth irrigated with $17 \%$ EDTA and $5.25 \%$ NaOCl followed by $17 \%$ EDTA showed significantly greater resistance to fracture than the groups irrigated with $5.25 \% \mathrm{NaOCl}$ and $2 \%$ Chlorhexidine.

Keywords: Chlorhexidine, EDTA- ethylene diamine tetra acetic acid, Endodontic irrigants, Fracture resistance, Sodium Hypochlorite $(\mathrm{NaOCl})$.
\end{abstract}

\section{Introduction}

The major objectives of root canal therapy are the removal of vital and necrotic tissues from the root canal system and obtaining a fluid-tight obturation and a coronal restoration. However endodontic treatment renders the tooth more prone to fracture. ${ }^{1}$ Resilon epiphany, an obturating system in which epiphany sealer forms a bond to the dentin walls as well as the Resilon core, forming a monoblock. ${ }^{2}$ Ex vivo studies have shown teeth obturated with resilon epiphany have shown greater resistance to fracture. ${ }^{3,4}$

Microorganisms are the prime etiologic factor for endodontic pathology, ${ }^{5}$ mechanical preparation of root canals alone cannot eliminate microorganisms, on the other hand evidence shows that portions of the root canal walls remain untouched after instrumentation and complete elimination of microorganisms by instrumentation alone is unlikely to occur. ${ }^{6,7}$ Therefore irrigation of the the root canal is essential to remove residual tissue and to kill microorganisms.

Chemical irrigants used have shown to alter the properties of dentin as well as the interaction between the dentin and resin based sealers. ${ }^{1,8}$ The most popular irrigating solution is sodium hypochlorite $(\mathrm{NaOCl})$. It is an effective antimicrobial agent and an excellent organic solvent for vital, necrotic and fixed tissues. ${ }^{9,10}$ Chlorhexidine has been proposed for use as an endodontic irrigant. In vitro antimicrobial activity of a $2.0 \%$ chlorhexidine endodontic irrigant was equivalent to that of $5.25 \%$ sodium hypochlorite. ${ }^{11}$ EDTA is a chelating agent,EDTA is also used with sodium hypochlorite and their combination has long proven to effectively remove smear layer. ${ }^{12}$

The purpose of this study was to evaluate the effect of different irrigating solutions on the reinforcing ability of resilon epiphany system of endodontically treated teeth.

\section{Materials And Methods}

Sixty single rooted mandibular premolar teeth were selected from a large random collection of extracted human teeth that were extracted for orthodontic purposes and stored in normal saline. Radiographs were taken in buccolingual and mesiodistal directions to confirm the teeth had a single canal. Ultrasonic Scaling was done to remove the soft tissues on the root surface. The teeth were decoronated and their length was standardized to $15 \mathrm{~mm}$ using diamond disks mounted on a straight micromotorhandpiece with a water spray. The 
actual canal length of each tooth was measured using observation of the apical exit of a size\#10 file (Maillefer, Ballaigues, Swiss) and this length of the file was measured using a millimeter scale. Working length was obtained by subtracting $0.5 \mathrm{~mm}$ from this length. The root canals were prepared with K-files (Maillefer, Ballaigues, Swiss) using stepback preparation technique. All canals were prepared to a master apical file size \#45 and coronal enlargement of the root canal was done to size \#80. A size \#10 file was used to recapitulate the canal $1 \mathrm{~mm}$ beyond its length between each file, in order to maintain patency. The teeth were then divided into four groups of 15 each. Irrigation was performed using a 27-gauge needle (Dispovan, Rajasthan, India) as follows:

Group1 (control): $1 \mathrm{ml}$ of distilled water between each file for $1 \mathrm{~min}$.

Group2: $1 \mathrm{ml}$ of 5.25\% Sodium hypochlorite (Dentapro, Chandigarh, India) between each file for $1 \mathrm{~min}$.

Group3: $1 \mathrm{ml}$ of 17\% EDTA (Prime Dental Product) between each file for $1 \mathrm{~min}$.

Group4: $1 \mathrm{ml}$ of $5.25 \%$ sodium hypochloritebetween each file for $1 \mathrm{~min}$, and $5 \mathrm{ml}$ of $17 \%$ EDTA after instrumentation for $5 \mathrm{~min}$.

In all groups, a final irrigation with $5 \mathrm{ml}$ of distilled water was performed for $5 \mathrm{~min}$ to remove debris and the irrigants.

The canals were conditioned using $10 \%$ polyacrylic acid applied using a pippette, irrigated with sterile water and dried using paper points (Maillefer, Ballaigues, Swiss). A standardized 45 size resilon(Pentron, Wallingford, CT, USA) was selected as master cone, introduced into the root canal to full working length and was checked for tugback. The canals were filled with the epiphany primer(Pentron, Wallingford, CT, USA) using a pipette. The epiphany sealer(Pentron, Wallingford, CT, USA) was dispensed and mixed on a mixing pad and the teeth were obturated using resilon with the lateral compaction technique.

Excess material wasseared off from the access cavity and resilon epiphany was light cured. The access cavity was sealed with Cavit G (3M ESPE). The quality of root canal fillings was confirmed radiographically using two radiographs in buccolingual and faciolingual directions.

The specimens were stored at $37^{\circ} \mathrm{C}$ for 10 days. The roots were then prepared for mechanical testing. All teeth were mounted vertically with dental stone in PVC rings, exposing 10mm of the tooth length. Fracture strength testing was done using a universal testing machine (Lloyd LR 50K, United Kingdom). A metal indenter of $5 \mathrm{~mm}$ diameter was fixed to the upper arm of the universal testing machine which was set to deliver an increasing load until fracture occurred. A cross head speed of $1 \mathrm{~mm} / \mathrm{min}$ was set and the load was applied vertically down to the long axis of the tooth. The force required to fracture each tooth was recorded in Newtons. The data thus obtained was evaluated statistically using One-Way ANOVA and Tukey's Post Hoc tests to determine the level of significance between different groups.

\section{Results}

The mean maximum load till fracture (newtons) and standard deviation for each group is presented in table1.

Group $4(5.25 \% \mathrm{NaOCl}+17 \%$ EDTA) yielded the highest mean resistance to fracture $(359.847 \mathrm{~N})$ and the lowest mean resistance to fracture $(253.380 \mathrm{~N})$ was recorded for group $2(5.25 \% \mathrm{NaOCl})$. There was no significant difference between groups 1 (distilled water) \& $2(5.25 \% \mathrm{NaOCl})$. There was significantly greater resistance to fracture for groups $3(17 \%$ EDTA) and $4(5.25 \% \mathrm{NaOCl}+17 \%$ EDTA), however, there was no significant difference between these two groups.

TABLE 1: FRACTURE RESISTANCE MEAN AND STANDARD DEVIATION OF THE GROUPS IN NEWTONS

\begin{tabular}{|l|l|l|}
\hline & Mean & Std. Deviation \\
\hline Group 1 & 269.287 & 64.8962 \\
\hline Group 2 & 253.380 & 64.4350 \\
\hline Group 3 & 343.733 & 61.1173 \\
\hline Group 4 & 359.847 & 90.6493 \\
\hline
\end{tabular}

TABLE 2: INTERGROUP COMPARISON OF FRACTURE RESISTANCE BETWEEN THE GROUPS

\begin{tabular}{|l|l|l|}
\hline (I) Group & (J) Group & P value \\
\hline 1 & 2 & .928 \\
& 3 & $.029^{*}$ \\
& 4 & $.005^{*}$ \\
\hline 2 & 3 & $.005^{*}$ \\
& 4 & $.001^{*}$ \\
\hline 3 & 4 & .926 \\
\hline \multicolumn{2}{|l}{$* \mathrm{p}<0.05$ Significant }
\end{tabular}




\section{Discussion}

Different irrigating systems may alter the chemical and structural composition of dentin, thereby altering its solubility and permeability characteristics. Hence affecting the adhesion of obturating materials to the dentin surface. ${ }^{13,14}$ Though the effects of each irrigant have been studied, the effects of irrigants on the tooth reinforcing capability of resilon epiphany is not known. In this study the irrigant used influenced the fracture resistance of teeth obturated with resilon epiphany.

Mechanical instrumentation usually results in amorphous irregular smear layer covering the canal dentinal surfaces and plugging the dentinal tubules, ${ }^{15}$ this would hinder the penetration of sealer into dentinal tubules. ${ }^{16}$ The removal of the smear layer could lead to greater sealer penetration into the exposed tubules, which may increase adhesion. ${ }^{17}$

Though chlorhexidine has a good antimicrobial activity, it lacks the ability to remove smear layer. ${ }^{18}$ The ability of $\mathrm{NaOCl}$ to dissolve organic tissues is well known and increases with rising temperature. However, its capacity to remove smear layer from the instrumented root canal walls has been found to be lacking. ${ }^{19,20}$ The incapability for chlorhexidine and $\mathrm{NaOCl}$ to remove smear layer hinders sealer adhesion to the dentin and hence inability to reinforce the tooth.

EDTA is a chelating agent and therefore capable of removing the smear layer. ${ }^{21}$ Relying on EDTA alone with activity against the inorganic matter only, however, results in incomplete removal of the smear layer. Complete cleaning of the rootcanal system requires the use of irrigants that dissolve organic and inorganic material. As hypochlorite is active only against the former, EDTA can effectively dissolve inorganic material, including hydroxyapatite to complete the removal of the smear layer and dentin debris. ${ }^{22}$

Therefore, teeth irrigated with $17 \%$ EDTA, $5.25 \% \mathrm{NaOCl}+17 \%$ EDTA show greater resistance to fracture than teeth irrigated with other irrigants.

\section{Conclusion:}

Under the conditions of this ex vivo study, better resistance to fracture for teeth obturated with resilon epiphany was observed using 17\% EDTA or 5.25\% NaOCl followed by 17\% EDTA as endodontic irrigants, than the regimens that used distilled water (control) or $5.25 \% \mathrm{NaOCl}$ for endodontic irrigation alone respectively. It is important to mention that further investigations should be conducted to evaluate the effect of different endodontic irrigants on clinical success of roots filled with resilon epiphany.

\section{References}

[1]. D Kishen A. Mechanisms and risk factors for fracture predilection in endodontically treated teeth. Endod Topics.2006;13:57-83.

[2]. Tay FR, Pashley DH. Monoblocks in Root Canals: A Hypothetical or a Tangible Goal. J Endod. 2007;33(4):391-8.

[3]. Baba SM, Grover SI, Tyagi V. Fracture resistance of teeth obturated with Guttapercha and Resilon: An in vitro study. J Conserv Dent. 2010;13:61-4.

[4]. Sakri MR, Shetty D, Hindhuja D, Byakod P, Nageswar R. RESILON - “ENDOBONDICS”.Pravara Medical Review. 2010;5(1):4-9.

[5]. Kakehashi S, Stanley HR, Fitzgerald RJ. The effects of surgical exposures of dental pulps in germ-free and conventional laboratory rats. Oral Surg Oral Med Oral Pathol Oral Radiol.1965: 20(3):340-9.

[6]. Peters OA, Laib A, Göhring TN, Barbakow F. Changes in root canal geometry after preparation assessed by high-resolution computed tomography.JEndod. 2001 Jan;27(1):1-6.

[7]. Byström A, Sundqvist G. Bacteriologic evaluation of the efficacy of mechanical root canal instrumentation in endodontic therapy. Scand J Dent Res. 1981 Aug;89(4):321-8.

[8]. Rocha AW, de Andrade CD, Leitune VC, Collares FM, Samuel SM, Grecca FS, et al. Influence of endodontic irrigants on resin sealer bond strength to radicular dentin.Bull Tokyo Dent Coll. 2012;53(1):1-7.

[9]. Bystro"m A, Sundqvist G. Bacteriologic evaluation of theeffect of 0.5 per cent sodium hypochlorite in endodontictherapy. Oral Surg Oral Med Oral Pathol Oral Radiol. 1983;55:307-12.

[10]. Gomes BPFA, Ferraz CCR, Vianna ME, Berber VB, Teixeira FB, Souza-Filho FJ. In vitro antimicrobialactivity of several concentrations of sodium hypochloriteandchlorhexidinegluconate in the elimination ofEnterococcusfaecalis. IntEndod J. 2001;34:424-8.

[11]. Jeansonne MJ, White RR. A comparison of $2.0 \%$ chlorhexidinegluconate and $5.25 \%$ sodium hypochlorite as antimicrobial endodontic irrigants. J Endod. 1994;20:276-8.

[12]. Hülsmann M, Heckendorff M, Lennon A. Chelating agents in root canal treatment: mode of action and indications for their use. IntEndod J.2003 Dec;36(12):810-30.

[13]. Doğan H, QaltS.Effects of chelating agents and sodium hypochlorite on mineral content of root dentin. J Endod. 2001 Sep;27(9):578-80.

[14]. Erickson RL. Surface interactions of dentin adhesive materials. Oper Dent. 1992;5:81-94.

[15]. McComb D, Smith DC. A preliminary scanning electron microscopic study of root canals after endodontic procedures. J Endod. 1975: 1(7):238-42.

[16]. White RR, Goldman M, Lin PS. The influence of smeared layer upon dentinal tubule penetration by plastic filling materials. J Endod. 1984;10:558-62.

[17]. P Tay FR, Loushine RJ, Weller RN, Kimbrough WF, Pashley DH, Mak YF, Lai CN, Raina R, et al. Ultrastructural evaluation of the apical seal in roots filled with a polycaprolactone-based root canal filling material. J Endod. 2005;31:514-9.

[18]. Mohammadi Z, Abbott PV. The properties and applications of chlorhexidine in endodontics. IntEndod J.2009;42:288-302.

[19]. Goldman M, Goldman LB, Cavaleri R, Bogis J, Lin PS. The efficacy of several endodontic irrigating solutions: ascanning electron microscopic study: Part 2. J Endod. 1982;8: 487-92.

[20]. Moorer WR, Wesselink PR. Factors promoting thetissue dissolving capability of sodium hypochlorite. IntEndod J.1982;15:187-96.

[21]. A. Khademi MS, M. Feizianfard MS. The Effect of EDTA and Citric Acid on Smear Layer Removal of Mesial Canals of First Mandibular Molars, A Scanning Electron Microscopic Study. J Res Med Sci.2004;2:80-8.

[22]. Haapasalo M, Shen Y, Qian W, Gao Y. Irrigation inEndodontics. Dent Clin North Am.2010;54:291-312 